[THIS PENULTIMATE VERSION MAY DIFFER IN MINOR WAYS FROM THE PUBLISHED VERSION. PLEASE DO NO QUOTE WITHOUT MY PERMISSION]

\title{
Is Early Foucault A Historian? History, history and the Analytic of Finitude.
}

There has been and still is much debate in the literature as to whether Foucault is (or not) a historian (as opposed to being a philosopher). When he became famous through the publication of The Order of Things, in 1966, many historians of ideas immediately attacked him for the alleged inaccuracy or mistaken character of his analyses ${ }^{1}$. At the same time, the French philosophical establishment rejected him for being too historical in his approach, to the extent that when the first large Foucault Colloquium was held in Paris in 1988, its (pro-Foucaldian) organisers felt that the title best suited to characterise and defend his work was "Michel Foucault Philosophe"2. Perhaps the latest example of this debate is the recent set of exchanges between G. Gutting and myself about my book, Foucault's Critical Project: Between the Transcendental and the Historical. While I read the Order of Things as trying to provide a philosophical analysis of the successive historical a priori in Europe, Gutting claims that "The Birth of the Clinic and The Order of Things are both primarily works of history, not philosophy in the traditional sense. In them, Foucault is concerned with forging a new approach to historical analysis but not with the metaquestion of how to understand or justify this approach philosophically" 3 . I certainly agree with Gutting that Foucault's analyses have a strong historical tenor: the bone of contention, however, concerns the way in which this historical element should be construed. In my view, The Order of Things attempts to re-interpret the Kantian critical project by providing what might be called a "transcendental history" ${ }^{4}$ of the conditions of possibility of knowledge in the West. By contrast, Gutting argues that he is an historian in the French tradition of the history of sciences (in particular G. Canguilhem) and thus preoccupied with empirical objects only. As suggested by Gutting's above remark about Foucault's methodology, this debate has consequences for the conception of philosophy which should be attributed to the latter (and on whether he should be seen as a philosopher at all): while Gutting sees any form of transcendentalism as a mistake (thus on my account Foucault would have "lapsed into transcendentalism", Gutting: §12), I argue that although Foucault strongly criticised the subject-based forms of transcendental philosophy (in particular Husserl's phenomenology), one of the most interesting aspects of his work, and part of what makes it specifically philosophical ${ }^{5}$, was precisely his attempt to historicise the transcendental and rethink it in a non subjective way.

\footnotetext{
${ }^{1}$ See for example: G. S. Rousseau: "Whose Enlightenment? Not Man's: The Case of Michel Foucault", Eighteenth Century Studies, n ${ }^{\circ}$ 6, 1972-73, p. 283-6; G. Huppert: "Divinatio and Eruditio: Thoughts on Michel Foucault", History and Theory n³, 1974; M. Pélorson: "Michel Foucault et l'Espagne”, La Pensée, $\mathrm{n}^{\circ} 152$, juillet-août 1970, or again J. Greene: "Les Mots et les Choses", Social Science Information, n6, 1967. ${ }^{2}$ A translation has been published as Michel Foucault Philosopher, London: Harvester Wheatsheaf, 1992. ${ }^{3}$ G. Gutting's review was published in the Notre Dame Philosophical Reviews (01/05/2003) and can be found at the following address: http://ndpr.icaap.org/content/archives/2003/5/gutting-han.html. There are no page numbers, but the passage I quote is in the fifth paragraph. I have written a reply to the review, which can be found at http://privatewww.essex.ac.uk/ beatrice/.

${ }^{4}$ I'll come back to this point later)

${ }^{5}$ (another very important element being his concern for truth: "If someone wanted to be a philosopher but didn't ask himself the question, 'what is knowledge?', or, 'what is truth?', in what sense could one say he was a philosopher? And for all that I may like to say I'm not a philosopher, nonetheless if my concern is with
} 
As I was reflecting on these issues, it occurred to me that perhaps the most productive path might be to take a fresh look at them by examining closely what Foucault himself has to say on history, considered both in itself and in its relation to philosophy. I have chosen to focus on The Order of Things as it is the core of the debate between Gutting and me but also (and mostly) because, strangely enough, it has not drawn much attention from commentators with respect to this specific question. Perhaps a reason for this is that even a quick survey shows that what Foucault means by "history" there is far from simple. Other well-known texts are clearly referring to history as historiography (thus both the "Réponse au Cercle d'épistémologie" (DE, I: 696-731) and the introduction to the Archaeology of Knowledge implicitly chart the mutations due to the rise of the Ecole des Annales and more recently the "histoire sérielle" in France). However The Order of Things undertakes a much more complex task: it is meant, not only to reflect on the current practices among historians (which it does, to some extent, in chapter X), but also and perhaps mostly to show how the rise of history as a discipline (and thus the surface debates about its methodology) were made possible by a deeper change, which Foucault calls a "too quickly sketched mutation from Order to History" (OT: 220, transl. mod.) and in which History (capitalised by Foucault) became "the fundamental mode of being of empiricities" (OT: 219). By contrast with chapter X, chapter VII is devoted to analysing this radical modification and to tracing its consequences, not only for historical practice (history with a lower case " $h$ "), but more generally for all the disciplines, including the human sciences and philosophy. In doing so, however, Foucault uncovers a second level to think of history (most often symbolised in The Order of Things by the shift to History with a capital "H"): as the new "radical mode of being" for "all empirical beings" (OT: 219), History is "not so very different from Order at the Classical age (OT: 219). In fact, it is our new historical a priori, whose appearance is the "fundamental event... whereby a positivity has constituted itself, from which we have probably not come out yet" (OT: 219). This claim, however, raises some very difficult questions: in particular, what is the relationship between History and Man (which chapters VII and IX identify as the ground of the post-Kantian épistémè)? This question has both epistemological (as the historical a priori is what allows us to know entities) and ontological ramifications, if it is true, as Foucault puts it, that History has become "the mode of being of all that is given to us in experience" (OT: 219, my italics). It also has important methodological correlates: in which ways are both history (as a discipline) and philosophy determined by History as the new historical a priori? More specifically, how do they relate to the Analytic of finitude (as the specific mode of thought generated by the ambivalence of Man as an empirico-transcendental double)?

My task in this paper will be twofold: firstly, I shall try to answer these questions, initially by reconstituting the meaning of the epistemic mutation from Order to History in chapter VII of The Order of Things, then by focusing on the very difficult chapter IX, where the connection between History, Man and temporality is explored through an investigation of the theme of the origin. Secondly, I shall use these analyses to return to the question of Foucault's methodology, in the hope that the analysis of his actual practice in The Order of Things will have done more to clarify the debate about the relation between history and philosophy in his work than my previous attempts.

As indicated above, the beginning of chapter VII is devoted to the analysis of an "alteration of the mode of being of positivities" (OT: 217) which took place during the last years of the XVIIIth century and whereby history became central to the way in which natural entities, human beings and language itself are understood. At first sight, this is hardly an original claim as it is a common place in the history of ideas that during that period theories appeared which focused on

truth then I am still a philosopher" (Power/Knowledge: Selected Interviews and Other Writings, 1972-1977, Colin Gordon ed., Brighton: Harvester Press, 1980, p. 66). 
the central part played by history in human and natural development, with such thinkers as Montesquieu, Herder or, obviously, Hegel. However what makes the claim interesting is the level at which this event should be understood: Foucault is not primarily concerned with describing the rise of historicism, nor the various ways in which history was construed (as being teleological, eschatological, etc). What he wants to uncover is what made both historicism and history possible, or more generally, "on the background of which historical a priori and in the element of what positivity ideas could appear (...), experiences be reflected in philosophies" (OT: XXII, transl. mod.). Chapter VII and the Preface make it very clear that it is at this archaeological level, that of the conditions of possibility of knowledge, that history should be conceived of 6 . "Obviously, History in this sense is not to be understood as the compilation of (...) sequences as they may have occurred; it is (...) [that] upon which [empiricities] are affirmed, posited, arranged and distributed in the space of knowledge [savoir] for possible knowledge [connaissances] and sciences" (OT: 219, transl. mod.). Properly understood, History (the capitalisation indicates the shift to the level of the épistémè) differs both from an "empirical science of events" and from « factual succession » (OT : 219). It "exists as much more than a probable form of succession: it constitutes a sort of fundamental mode of being" (OT: 276). To put it in the traditional Hegelian terms, History is neither historia rerum gestarum (history of past deeds) nor res gestae (the deeds themselves) ${ }^{7}$ : it is their joint condition of possibility.

That Foucault thinks so is made clear by the analogy he draws between History in the modern age and Order in Classical thought. Order, he tells us, was not merely an empirical arrangement of entities: far from being "the visible harmony of things, or their observed arrangement", it was the "particular space of their being and that which, prior to any knowledge [connaissance], established them in knowledge [savoir]" (OT: 219, transl. mod., my italics). Thus during the classical age, order was neither imposed a posteriori by our classifications or hierarchies nor read off existing arrangements by inductive processes. On the contrary, it was what made it possible for us to have the kind of hierarchies we had, and this, before the acquisition of any specific knowledge content (connaissance). It opened a space for thought, that of "savoir", on the background of which all entities could be understood as orderable, and this before any actual ordering had taken place. During the Classical age, the existence of such a space was ultimately dependent on an isomorphism between language and representation, which allowed entities to be uncovered as fully representable within discourse. Thus Descartes could be a priori confident in the possibility of decomposing our thoughts in simple elements and of re-arranging them by degree of complexity in such a way that a fully adequate picture of the world would be attained. Now Foucault's contention in The Order of Things is that History is the new form taken by order. It is "that in which, before any established chronology [the empirical] acquires its specific mode of being" (OT: 231, my italics). Just as order was the non empirical precondition of the arrangement of things and thought in the Classical age, History is the condition of possibility of chronological succession (since the anteriority Foucault points out would not make sense if it itself was of a chronological nature). Thus the reason why we now think of all entities as historical (as opposed to being transparent to linguistic representation) is not that we have studied a posteriori their transformations, or imposed a temporal order on them from the outside: on the contrary, it is because History has become our new épistémè, the "mode of being of everything that is given to

\footnotetext{
${ }^{6}$ Thus the Preface defines History as "a new form of order imposed by the coherence of time" (OT: XXIII, transl. mod.). I'll come back to the relation between History and temporality in a little while.

${ }^{7}$ The distinction was introduced by Hegel in the following passage : "in our language, the word "history"

[Geschichte] combines both objective and subjective meanings, for it denotes the historia rerum gestarum as well as the res gestae themselves, the historical narrative and the actual happenings, deeds and events which, in the stricter sense, are quite distinct from one another". (Lectures on the Philosophy of World History, Cambridge: Cambridge UP, 1975, p. 137 (second draft, 1830).
} 
us in experience" (OT: 219), that we are led to see entities as historical. Perhaps a contrast with the part played by history within the previous épistémè can be of help here. According to Foucault, the Classical age did recognise the importance of history but saw it merely as one of the contingent variables which could influence a species whose essence could still be determined $a$ priori. Thus although history played a part in the tables drawn up by natural history, for example, it was as an extraneous factor, a perturbation of a pre-established type (on the same level as geological disasters): "for eigthteenth century thought, chronological sequences are merely a property and a more or less blurred expression of the order of beings" (OT: 276). By contrast, from the XVIIIth onwards, empiricity (...) is henceforth traversed by History through the whole density of its being" (OT: 293). History comes to be seen as the very medium in which beings develop and acquire characteristics which in turn cannot be considered or explained independently of this development - perhaps one of the clearest examples of this would be Darwin's theory of evolution.

Before proceeding any further, we should note that there is a potential difficulty with this formal characterisation of History as the new épistémè. The problem stems from the fact that even if one sticks to the archaeological level, History remains ambiguous: it is defined both as an epistemological condition of possibility (it is "the space from which all beings come to knowledge", OT: 219) and as an ontological condition (it is the "fundamental mode of being of empiricities", OT: 219). Yet at first sight, it is not clear how the same thing can be both the (subjective) condition under which entities are known, and a seemingly objective property of the same entities. Very significantly, Foucault's characterisation of Order in the Preface exhibits the same ambiguity: "order is at one and the same time that which is given in things as their inner law (...) and also that which has no existence except in the grid created by a glance, an attention, a language" (OT: $\mathrm{XX}$, transl. mod.). There are two uncharitable ways to look at this ambiguity: the first one is to say that it commits Foucault to a form of subjective idealism (things are what they are because they and their properties are dependent on being known by us for their existence: thus we make things historical by knowing them as historical). While this may seem to resonate with the nominalism he later professed ${ }^{8}$, and more generally with the idea that theoretical objects are constituted through practices and discourses, it differs from it in a significant way: throughout his career Foucault remained a realist in the sense that he never doubted the existence of empirical objects, nor claimed that these were constituted through our practices (which is the subjective idealist's position). This is made very clear, for example, by the distinction he draws between "sexuality" (a historical construct born at the end of the XVIIIth century) and "sexual practices" (which, he says, have always existed). So Foucault is not a subjective idealist. The second uncharitable way to look at his position is to conclude that he is getting confused between the ratio essendi and the ratio cognoscendi of entities, i.e. between conditions of existence and conditions of knowledge, and that what he really should be saying is that we can know that things are historical because they are historical (independently of us). However this conclusion is invalidated by the following two reasons: firstly, it would suggest that the only way we can know that things are historical is through empirical induction, which Foucault specifically denies (History is prior to any chronology). Secondly, the very point of writing an archaeology of the successive épistémès is to show that any claim to truth must be recontextualised within the epistemic space of truth it belongs to. Thus the claim according to which entities are historical per se can only make sense from the epistemic perspective it stems from, i.e. that of History as our historical a priori, which in turn invalidates its pretension to universality. By contrast, the beings whose characteristics are detailed in the tables of the classical age were not historical.

\footnotetext{
${ }^{8}$ Cf. in particular the « Table ronde du 20 Mai 1978 », in L'Impossible Prison, M. Perrot ed., Paris : Seuil, 1980, p. 56).
} 
Given these aporia, it seems to me that the solution to the ambiguity of History requires that the relation between conditions of knowledge and conditions of existence should be construed otherwise. Perhaps not surprisingly given the importance Kant had for Foucault, I would suggest that his position is in fact analogical (but not identical) to Kant's. The dilemma caused by Foucault's ambiguous definition of History is certainly the very one that Kant tried to solve by finding a way between Berkeleyan idealism on the one hand, and Humean empiricism on the other. In Kant's time, it found a particular focus on the problem of causality, the question being whether it is in the mind or in nature. As is well known, Kant's solution consisted in saying that it is both in the mind and in nature, or rather, that the reason why it can objectively said to be in nature is that natural phenomena are constituted as such through the application of the pure categories of the understanding, to which causality belongs. In a similar way, time and space are both a priori forms of sensibility and objective features of phenomena because the latter can only be determined as phenomena through a universal spatio-temporal framework. This is neither a type of empiricism (as phenomena are dependent on a priori conditions for their constitution) nor a kind of subjective idealism (since neither the application of the framework nor that of the categories creates their object in a causal sense, which would only be the case for an intellectus originarius).

The connection between conditions of knowledge and modes of being established by the quotes cited above suggests that Foucault did have such a solution in mind. In fact, it seems to be the only position which allows us to make sense of his characterisation of History without attributing to him theoretical views which he explicitly rejected. According to this reading, what Foucault means by saying that History is both the condition under which entities are known and their mode of being, then, is that History has become the very framework (in his terms, the historical a priori) under which they are constituted as the entities they are. It does not mean that their historicity is an arbitrary construction of the mind, as Foucault makes it clear that we do not choose our épistémè; on the contrary, we are bound to construe beings as historical by the fact that we are governed by History, and this until a new épistémè arises (such as the "Return of language"). Significantly, this idea that conditions of knowledge (in the wide sense of "savoir") are intrinsically linked with the ontological characterisation of objects is central to one of the few definitions of the historical a priori in The Order of Things, as what "in a given period, carves out in experience a field of possible knowledge [savoir], [and] defines the mode of being of the objects which appear in that field' (OT: 158, transl. mod., my italics). This interpretation also has the additional benefit to allow us to make sense of the pluri-realism which underlies The Order of Things, and finds a clear expression in the following quote:

suddenly things are not perceived, described, stated, characterised (...) in the same way, and that it is no longer wealth living beings and discourse that are presented to knowledge in the interstice of words or under their transparencies, but radically different beings" (OT: 217, transl. mod., my italics).

The new beings are "radically different" because they are constituted under a different historical a priori (History): yet it does not mean that the previous ones were illusory. They were just as real, but under the different epistemic conditions which governed their constitution (in this case, order in the Classical age $)^{9}$. Two important qualifications must be introduced, however, if the analogy between Foucault's position and Kant's transcendental idealism is to work: firstly, contrary to Kant, Foucault does not think that the conditions of possibility of knowledge can be characterised

\footnotetext{
${ }^{9}$ As I have explained elsewhere, this has consequences for Foucault's theory of truth. Just as beings are dependent on their épistémè for their constitution, in the same way it is only within the specific space of "acceptability" defined by the historical a priori that propositions can count as true or false. See Foucault's Critical Project, p. 73-108.
} 
as universal and a-temporal, although he does say that each épistèmé holds sway completely over a specific period of time. On the contrary, they are subject to change, and thus historical (which, according to the logic of transcendental determination just described, may be a reflection of the fact that History still governs us as an épistémè). Secondly, for Kant these conditions must be referred to the interplay of the faculties of the transcendental subject, and thus ultimately to human sensibility, imagination and understanding. Yet Foucault strongly denies that this must necessarily be the case: as we shall see, it has been the case from Kant onwards because of the deep connection between History as an épistémè and Man as an empirico-transcendental double. But the purpose of archaeology is precisely to provide a revised interpretation of the transcendental which preserves the idea of an a priori (in the relative sense just defined) determination while severing its connection to the subject.

Having solved this difficulty, we are now in a position to return to Foucault's account of the birth of History and its consequences on modernity. Since all beings are now pre-determined as historical, thought acquires the new task of finding ways to understand this historicity and of making it explicit. Thus "philosophy in the XIXth century ${ }^{10}$ will lodge itself in the distance from history to History, from events to the Origin, from evolution to the first rending [déchirure] of the source" (OT:219, transl. mod.). Before examining the rather obscure ending of quote (which "Origin"? Why capitalise the term? What is the "first rending of the source"?), it may be useful to focus on its beginning and to see what Foucault has in mind by means of an example. As suggested by the parallel between "history" on the one hand, events and evolution on the other, history here refers to empirical historical development, in Hegel's terms the res gestae. The problem for philosophy thus become to work out a narrative which will make sense of the relation between empirical events and History as the historical a priori which allows them to be understood as historical. In Foucault's view, this new imperative explains the XIXth century's various attempts to recontextualises history within a wider conception of becoming as well as the emergence of a new form of understanding of philosophy as historical self-critique. These two dimensions are perfectly exemplified by Hegel's work.

[Philosophy] will lead thought back to the question of knowing what it means for thought to have a history. This question will indefatigably drive philosophy from Hegel to Nietzsche and beyond. But we must not see this as the end of an autonomous philosophical reflection, too morning-like and too proud to examine exclusively what was said before it and by others; let us not use this as a pretext for disparaging a thought powerless to stand on its own feet, and always forced to wrap itself around an already accomplished thought". (OT: 220, transl. mod.).

Although it is fairly allusive, this passage can be seen as a pithy summary of Hegel's relation to the rationalist tradition on the one hand, and of his conception of philosophy on the other ${ }^{11}$. Descartes (the "morning" of rationalism) sought to establish philosophy as a presuppositionless and thus autonomous method; this motivated his well-known rejection (at the beginning of the Meditations) of the scholastic teachings he received at La Flèche ("what was said before it and by others"). By contrast, Hegel sees philosophy itself as part of a historical process which it cannot be

\footnotetext{
${ }^{10}$ The rest of the quote (cited below) makes it clear that this does not apply to the XIXth century only. Foucault mentions "Hegel, Nietzsche and beyond".

${ }^{11}$ Foucault knew Hegel well: he studied with Jean Hyppolyte and wrote his D.E.A manuscript (now lost) on:

"La constitution d'un transcendental historique chez Hegel" ("The Constitution of a Historical

Transcendental in Hegel").
} 
severed from: it is the self consciousness of a particular society, the embodiment of its values ${ }^{12}$. Correlatively, philosophy is given a new goal: to form an awareness of its own historical genesis. The very fact that thought cannot "stand on its own feet" anymore and has to "wrap itself around" its past does not count for Hegel as an argument against philosophy; on the contrary, it motivates the need for a new, critical form of historicism whereby philosophy's reflection on its own history becomes the completion of the Kantian project by allowing it to understand its historical preconditions ${ }^{13}$. Thus with Hegel, "philosophy, freed from a certain metaphysics because it has been freed from the space of order, is devoted to time", and this, not only because it has history (as res gestae) as its object, but also because it is, as an activity, "taken up in the mode of being of History" (OT: 220, transl. mod.).

Yet although he sees Hegel as highly representative of the changes brought by the rise of History, Foucault does not think that the latter succeeds particularly well in capturing the real meaning of our new épistémè. On the contrary, chapter IX places Hegel in with what Foucault calls the "metaphysics of the object" and rejects his teleology as resting on unjustified metaphysical assumptions (such as the rationality of the real, or more generally the claim that absolute knowledge is possible ${ }^{14}$ ). According to him, the same criticism applies, in different ways, to Marx's eschatology and to Spengler's inverted Hegelianism in The Decline of the West ${ }^{15}$. Thus the task remains

set to thought: that of (...) recovering the mode upon which the possibility of time is constituted - this origin without origin or beginning on the basis of which everything is able to come into being (...) — in such a way as to make visible that rent, devoid of chronology or history, from which time issues (OT: 332).

Since this passage uses the same opaque rhetoric as the previously quoted one ${ }^{16}$, it is difficult at this point to determine what Foucault means exactly. Two things are clear, nevertheless: firstly, this task involves going from history (as empirical succession) to its conditions of possibility, which themselves are not historical ("an origin without origin or beginning", a "rent devoid of chronology or history"). The thematic and rhetorical parallels with the previous quote strongly suggest that these conditions of possibility are strongly connected to History. In turn, this confirms that the specific task of philosophy is to go from the post hoc to the a priori (in Foucault's revised sense of the a priori), a point to which I'll come back later. Secondly, the proper way to understand History is to clarify its connection with time: yet this cannot be done in an empirical way (i.e. by charting various empirical successions and establishing chronologies for them) as this would be tantamount to presupposing what needs to be explained (because of the epistemic dependency of history on History). What is required is an archaeological analysis of the constitution of time itself ("the mode under which the possibility of time constitutes itself"), which logically pre-exists the time of succession and does not belong to it. In Foucault's terms, this involves an investigation into History as an origin (by opposition to beginnings, which are

\footnotetext{
${ }^{12}$ (hence the famous passage in the Philosophy of Rights. "philosophy is its own age comprehended in thought" (Preface, VII, 26)).

${ }^{13}$ On these issues, see Frederick C. Beiser, « Hegel's Historicism », in The Cambridge Companion to Hegel, Cambridge: Cambridge UP, 1993.

${ }^{14}$ On this issue, and more generally on Foucault's reconstruction of the evolution of philosophy after Kant, see B. Han-Pile, "Analytic of finitude and the History of Subjectivity, in the forthcoming edition of The Cambridge Companion to Foucault (ed. G. Gutting).

15 (London G. Allen and Unwin, 1932).

16 ("philosophy in the XIXth century will lodge itself in the distance from history to History, from events to the Origin, from evolution to the first rending [déchirure] of the source" (OT:219, transl. mod.)
} 
homogeneous to what they begin: for example, the event which is traditionally used by historians to determine the beginning of history, i.e. the invention of writing, is itself an historical event).

It is at this crucial point that the two strands of chapter VII and chapter IX connect: we have seen that chapter VII identified History as the new épistémè replacing Order in Classical thought. As it is well-known, Chapter IX redescribes the same shift as the rise of anthropology, itself understood as "the fundamental arrangement that has governed and controlled the path of philosophical thought from Kant to us" (OT: 342). Thus

When (...) Classical discourse, in which being an representation found their common locus, is eclipsed, then, in the profound upheaval of such an archaeological mutation, man appears in his ambiguous position as an object for knowledge and a subject that knows, subjugated sovereign, observed spectator, he appears in the place belonging to the King, which was assigned in advance to him by Las Meninas but from which his real presence was for so long excluded" (OT: 323, transl. mod., my italics).

Most of chapter IX is devoted to explaining the ways in which Man, as an empirico-transcendental doublet ("object for knowledge and subject that knows"), forms the underlying structure of our épistémè ${ }^{17}$. Foucault's conclusion is that the "Man's mode of being as constituted in modern thought, is (...) simply that historical a priori which, since the XIXth century, has served as an almost evident ground for our thought"18 (OT: 344, my italics). If such is the case, then there must be a deep connection between History and Man (as Foucault holds that two different épistémès cannot coexist at the same time, each holds sway completely over its own period ${ }^{19}$ ); from what we have seen in the previous paragraph, this connection must involve the constitution of temporality. Not surprisingly, this is exactly what Foucault claims in the following passage:

it is in [Man] that things (...) find their beginning; rather than a cut, made at some given time in duration, he is the opening from which time in general can constitute itself, duration flow and things make, at their specific time, their appearance (OT: 332, transl. mod.).

Thus the archaeological investigation about the nature of History must, ultimately, involve an inquiry into the nature of Man and his relation to temporality. Whatever the results of such an investigation, we already know that neither History nor Man belongs to empirical succession (Man is not "a cut made at some given point in duration"): on the contrary, they make it possible. We now need to develop this connection, and understand its relation to the theme of the origin whereby the shift from history to History was initially introduced by Foucault.

Perhaps the best starting point is contrast established in chapter IX between the part played by the origin during the Classical age and its role in current thought. "To recover the origin in the XVIIIth century", Foucault tells us, "was to place oneself once more as near as possible to the mere doubling of representation" (OT: 329). Like the entities or events that were referred to it,

\footnotetext{
${ }^{17}$ Foucault sees Kant's refocusing of the three critical interrogations on the question "was ist der Mensch" as the prefiguration of this focusing of the contemporary épistémè on Man. Cf. Foucault's Critical Project, part I. See also "Analytic of Finitude and History of Subjectivity", where I show that for Foucault, the empiricotranscendental structure governs the whole development of philosophy since the XIXth century.

${ }^{18} \mathrm{Cf}$ also : «c'est sur l'analyse de ce mode d'être [celui de l'homme] et non plus sur celle de la représentation que depuis le XIXème siècle la réflexion cherche à fonder philosophiquement la possibilité du savoir »(OT : 345).

19 "In any culture and at any given moment in time, there can only be a single épistémè which defines the conditions of possibility of all knowledge" (OT: 179).
} 
the origin itself was a representation (thus the origin of language was "the transparency between the representation of a thing and the representation of the cry (...) which accompanied it", OT: 329). As such, it was fully insertable in the Classical tables and did not play a particularly important role in the organisation of knowledge ("it was of little importance whether this origin was considered as fictitious or real, whether it possessed the value of an explanatory hypothesis or as a historical event" (OT: 329). By contrast, the theme of the origin becomes central to modern thought insofar as it provides the junction between History and Man. As could be expected given Man's ambivalent structure as an empirico-transcendental double, the origin acquires an ambiguous meaning, made even more difficult to understand by the complexity and often allusive nature of Foucault's text. At a first, empirical level, the origin is thought of independently of Man, as the endlessly receding temporal beginning of such empiricities as life, language and labour. As we have seen, because of the shift from the age of representation to that of History and of the dissolution of the transparency between being and language, things have become "involuted upon themselves" and have acquired their autonomy from thought. As a result, they "display but by means of their own laws, the inaccessible identity of their origin" (OT: 330). What makes the origin of things elusive is that it belongs to such a distant past that man has no direct experience of it and can never be sure to recapture it in thought. Thus "man is never contemporary of this origin which through the time of things is both drawn and withdrawn" (OT: 330, transl. mod.). In this sense, the existence of the origin is a mark of human finitude, as it signals the autonomy of empirical contents which have their own history, pre-exist us and over which we have little power. In the Hegelian terms used above, it presupposes and indicates the independence of the res gestae from any human life or narrative.

However, this is not the only, nor even the primary meaning for the origin. As we have seen, for Foucault both historia and res gestae are dependent on History as an historical a priori in the sense that it is their condition of intelligibility. Given the connection between History and Man, this means that even though it is causally independent from human beings, the origin in the empirical sense must nevertheless be epistemically dependent on man as an empiricotranscendental doublet. This is confirmed by a previously cited passage, which we must now quote and examine more fully:

On the one hand (...) the origin of things is always pushed further back, since it goes back to a calendar upon which Man does not figure; but on the other hand (...) it is in him that things (...) find their beginning; rather than a cut, made at some given time in duration, he is the opening from which time in general can constitute itself, duration flow and things make, at their specific time, their appearance (OT: 332, transl. mod.).

What Foucault signals here is a reversal of the relation between man and the origin, a reversal made possible by the shift from the empirical to the transcendental: although the (empirical) origin of things escapes us, man himself is the (transcendental) origin of the history of things in that he is the condition of possibility of time itself. This reversal is characteristic of the movement of the analytic of finitude as what reveals the epistemic dependence of empirical forms of finitude on their transcendental counterpart ${ }^{20}$ : "thus from the heart of empiricity is indicated the

\footnotetext{
${ }^{20}$ On this point, see B. Han, « Heidegger and Foucault on Kant and Finitude”, in A. Milchman (ed.), Critical Encounters : Heidegger/Foucault, (Indianapolis: Indiana University Press, 2003). where I have shown that to understand the analytic of finitude, one must distinguish between two forms of finitude: empirical finitude on the one hand, (i.e. the fact that man is a living, working, speaking being, and thus dependent on contents and forms which he does not master), and transcendental finitude (as the absence of intellectual intuition) on the other. The analytic of finitude is the movement whereby empirical finitude is shown to be dependent
} 
obligation to go back, or if one likes to descend, to an analytic of finitude where the being of man can found in their positivity all the forms which indicate to him that he is not infinite" (OT: 326). Life, labour and language exist independently from us, and have their own history; however both their existence and the fact that they can have a history depend on us in so far that without us they couldn't appear as what they are. While man is finite in that he is determined by the various empiricities he belongs to (and thus is subject to the laws of biology, of economics etc), he nevertheless "founds" them, as Foucault puts it, in that he makes it possible for them to be intelligible as such. So although the origin (in the first sense) of things is causally independent from us, at the level of the historical a priori it is epistemically dependent on man's finitude construed at the transcendental level (for example as the absence of intellectual intuition for $\left.\mathrm{Kant}^{21}\right)$. This conclusion is stated very clearly in the following passage:

thus behind the history of positivities, there appears another, more radical, history, that of man himself. (...) At a very deep level there is a historicity of man (...) which is also the radical dispersion that provides a foundation for all other histories (OT: 370, my italics).

So chapter IX shows that History is ultimately grounded in Man. Because of this grounding, the empirical history in which things have their own independent origin must be referred to Man as the transcendental origin of time. However, although the logic of Foucault's analyses of the origin is clear, the difficulty is that their content remains very formal. Rather frustratingly, The Order of Things does not explain how the relation of man to temporality should be construed, nor why it is a "radical dispersion". As we have seen, Foucault clearly rejects any empiricist or positivist approach which would derive the idea of time from the observation of phenomenal succession. But his description of originary temporality is so vague that it could refer to any of the non empirical accounts of time developed after the end of the Classical age. Each in their way, Kant, Husserl or Heidegger (just to mention a few) claimed that empirical time cannot be understood from itself and requires the shift to another perspective whereby a more originary connection between man and time can be explored. Thus Kant thought that in order to understand empirical time, one has to shift to the perspective of the Transcendental Aesthetic, where time appears as a form of sensibility and thus an a priori condition of possibility of experience; Husserl suggested that objects derive their temporal character from our consciousness of time, which itself must be transcendentally analysed as the continual synthesis between retention and protention whereby the flow of original temporality is constituted. As for Heidegger, he claimed that the everyday time of human experience, the time of clocks and bells, does not depend on the intentional activity of consciousness but must be derived from our projective experience of primordial temporality. Which, if any, of these accounts does Foucault have in mind, when he speaks of man as "the opening from which in general time can constitute itself and duration flow" (OT: 332)? The notion of an "opening", coupled with the theme of constitution, seems to indicate Kant, while the idea of duration as a "flow" suggests Husserl (the Kantian term would be "succession", as in the Analogies of experience). The joint theme of an originary "dispersion" of man does not make much sense in Kantian terms (since for him time unifies experience) but could be referred both to Husserl and to Heidegger (because of the tension between protention and retention for the first, and of the ecstatic character of Dasein's understanding of temporality for the second). The last passage (other than the previously quoted ones) in which Foucault touches upon these issues is not very helpful. Its beginning could suggest that Foucault has Heidegger in mind:

on transcendental finitude. Thus although we are causally determined by life, labour (etc), they are dependent on us to be understood and known as such.

${ }^{21}$ (Foucault develops the theme in his commentary to Kant's Anthropology) 
And thus, in this infinite task of thinking the origin as close and as far away from itself, thought reveals that man (...) is caught within a power which disperses him (...); now this power is not foreign to him (...); this power is that of his own being. Time - the time he is himself (OT: 335, transl. mod.).

However, if this was meant as an allusion to Heidegger, then Foucault would be equating Dasein with Man, and thus misunderstanding an important dimension of Heidegger's work, namely his rejection of the primacy of consciousness and of the transcendental as a detached starting point ${ }^{22}$. The rest of the passage does not give any further clues and just reasserts a) the dependency of empirical time on a more primordial understanding of temporality as origin and b) of empirical finitude on its transcendental counterpart understood as the fundamental relation of man to time:

in the modern experience, on the contrary, the withdrawal of the origin is more fundamental than all experience, since it is in it that experience shines and manifests its positivity. (...) And here we meet again the initial theme of finitude. But this finitude which was expressed first by the way things hung over man (by the fact that he was dominated by life, history and language) now appears at a more fundamental level: it is the insurmountable relation of man's being with time (OT: 335, transl. mod.).

Thus the allusive character of Foucault's prose in chapter IX makes it impossible to determine precisely which (if any) of the above approaches he has in mind. Although its necessity has been formally demonstrated, the connection between Man and time - and so the ground of History as an épistémè — remains obscure. Yet before faulting Foucault for his vagueness perhaps we should consider the two following points. Firstly, the very fact that all these accounts share the same structure suggests that he is right, both in seeing the distinction between the empirical and the transcendental as the epistemic ground of modernity and in identifying the analytic of finitude as the correspondingly dominant method for uncovering this ground. Secondly, it is quite possible that his uncertainty should not be construed as an argument against him, but rather as the consequence of his belonging to the very épistémè he was trying to describe. Part of the thrust of The Order of Things is to show that no theory can be formed outside of the space opened up by the historical a priori, which, "in a given period, (...) defines the conditions in which [one] can hold a discourse about things that is recognised to be true" (OT: 158). This is developed in his inaugural lecture at the Collège de France, The Order of Discourse, in which Foucault shows, through the example of Mendel and Schleiden, that there is no external, objective standpoint from which eternally true propositions could be formulated ${ }^{23}$. Consequently, any discourse must reflect the conditions of its birth. However, this does not mean that it does so in a transparent or selfaware way. On the contrary, it is only from the perspective of another épistémè that the former one can be uncovered as what unified the discourses of a previous period. Thus while it is possible for Foucault to lay out the epistemic foundations of the Renaissance or of the Classical age, by the same token, the foundations of his own épistémè must remain obscure to him. The only reason why he is able to partially uncover them is that he belongs to the cusp of a new épistémè, the "Return of Language". This liminary position gives him a greater critical distance than was available to, say, Kant or Husserl, but it does not allow him to transcend the limits of his epoch

\footnotetext{
${ }^{22}$ I have argued « Heidegger and Foucault on Kant and Finitude" that for Foucault, Heidegger comes closest to escaping the Analytic of Finitude.

${ }^{23}$ See L'ordre du discours, Paris: Gallimard, 1971, in particular p. 37 sq. For an analysis of what Foucault has in mind by « being in the truth » and the idea that the space of truth has no "outside", see Foucault's Critical Project, part II chapter 1.
} 
and see its foundations clearly. So while Foucault can say with certainty that the connection between History and Man has formed our historical a priori so far, by definition he is not able to clarify it fully.

However, this liminary position also gives him a greater insight than was previously available into the problems generated by this grounding of History in Man, and more generally by the analytic of finitude. As we have seen, the latter's logic consists a) in going from empirical contents to their transcendental conditions of possibility and b) in identifying these conditions with Man considered in his transcendental capacity. The meaning of the analytic of finitude thus resides in trying to overcome man's empirical limitations (according to which he is, as a living, working and speaking being, determined by empiricities he neither chooses nor controls) by means of a shift to the perspective of transcendental determination. This new perspective reveals that the very empiricities which (causally) determine him as an empirical being are dependent on his existence as a transcendental subject to appear as such. The analytic of finitude is the movement which "constantly leads from the positivities which determine [causally] the being of man to the finitude that allows these very positivities to appear [transcendental finitude] ${ }^{24 "}$ (OT: 383). Thus man is uncovered as "a being whose enigmatic reality constitutes, prior to all knowledge, the order and connection of what it has to know" (OT: 244, my italics). Yet there is a third aspect to the analytic of finitude, whereby this foundational logic is defeated: it is the impossibility, originating in Kant's transition from the Critique to the Anthropology, of thinking the connection between the transcendental and the empirical within Man. Perhaps significantly (given the grounding of History in Man), this impossibility is first analysed by Foucault with respect to temporality ${ }^{25}$. Through the examples of Kant, Husserl and Heidegger, we have seen that the original intention of the Analytic of finitude was to refer empirical succession to a more originary form of temporality, which makes it possible. According to this logic, the two understandings of time were carefully distinguished (which in turn required additional theoretical moves to reconnect the first to the second). However Foucault questions the possibility of such a neat separation; if one leaves the theoretical perspective of knowledge for that of existence (which is required by the very nature of Man), then the "a priori of knowledge (...) appears in the density of a becoming where its sudden emergence infallibly takes on the retrospective sense of the already there" (C: p. 60, my translation). In the less abstract but very similar terms of The Order of Things,

\footnotetext{
${ }^{24}$ See also: "each of these positive forms in which man can learn that he is [empirically] finite is given to him only against the background of his own finitude" (OT: 314).

${ }^{25}$ The problematic relation between the empirical and the transcendental established by the Analytic of finitude is also analysed from the perspective of a further reversal between causal and epistemic determination. As we have seen, objects and more generally the world require transcendental constitution to appear as such; thus man's "enigmatic reality constitutes, prior to all knowledge, the order and connection of what it has to know" (OT: 244). Yet because man is an existing being, thrown in medias res, such a constitution cannot be thought of as a detached starting point. The very way in which we open up the world reflects the empirical and historically circumscribed conditions which determine us as living, working and speaking beings. This means, in turn, that epistemic determination cannot be thought of as independent from causal relationship. Because of this, the analytic of finitude is ultimately uncovered as "a mode of thought in which the rightful limitations of knowledge (and consequently all empirical knowledge) are at the same time the concrete forms of existence, precisely as they are given in that same empirical knowledge" (OT: 248). Thus "life, language and labour appear as so many "transcendentals" (...), they are conditions of knowledge" (OT: 244): as another passage puts it, "the contents of experience are already their own conditions" (OT: 350). Worse, due to the withdrawal of being from representation which marked the end of the Classical age, there is no way these contents can be fully clarified ("in their being, [the quasitranscendentals] are outside knowledge", OT: 244). Thus the analytic of finitude is left with the impossible task of "revealing the conditions of knowledge on the basis of the empirical contents given in it" (OT: 319)
} 
as soon as he thinks, man unveils himself to his own eyes in the form of a being who is already, in a necessarily subjacent density, in an irreducible anteriority, a living being, an instrument of production, a vehicle for words which exist before him" (OT: 313, my italics).

Because of the dual nature of man, both empirical and transcendental, the moment of transcendental constitution ("as soon as he thinks"), which considered in itself is not temporal but opens up the possibility of time, must be replaced within the empirical succession which depends on it. This generates a paradox (as a condition of possibility should not be homogeneous to what it conditions) whereby transcendental determination can only appear as somehow pre-existing itself in the chronological time it generates ("already there", "irreducible anteriority") in a past analogical to the "primitivity" analysed by Derrida in the work of Husserl ${ }^{26}$. Thus the origin of time becomes "in concrete existence an originary which (...) as soon as it appears reveals itself as an already there" (C: 60).

This analysis allows a third meaning for the origin to emerge in chapter IX: from this new perspective, it is neither the autonomous origin of things, nor man as the origin of time, but the ambiguous "fold" (OT: 330) of the one on the other, i.e. the originary $^{27}$ as the endlessly receding relation between the time of things and originary temporality. Thus

the originary in man is what from the start articulates him from the very outset upon something other than himself: it is that which introduces into his experience contents and forms older than him, which he does not master. (...) Paradoxically, the originary in man does not herald the time of his birth (...); it links him to that which does not have the same time as himself (OT: 331).

According to the retrospective logic analysed above, the originary is not itself a temporal point:

It is always on the background of the already begun that man can reflect on what may serve for him as origin. For man, then, it is not at all the beginning — a sort of early morning of history from which later acquisitions would have accumulated" (OT: 330, transl. mod).

On the contrary, it is the way in which man thinks his paradoxical inscription in the pre-existing history of things which can only be said to pre-exist him from the very temporal perspective he opens up. As a "thin surface which accompanies [longe] our entire existence" (OT: 330-1), the originary cannot neither be pinpointed nor fully clarified: as indicated by a previous quote, it recedes in a "necessarily subjacent density [in the etymological sense of sub-jacere, i.e. lie under]" which resists clarification. Thus “[Man's] knowledge is limited, diagonal, partial, since it is surrounded by an immense shadowy region where labour, life and language conceal their truth (and their own origin) from those very beings who who speak, exist and are at work" (OT: 331, transl. mod.)

So History, the new épistémè generated by the end of the Classical age, is ultimately revealed as a rather problematic configuration. Because we are determined by it, we now see both entities and thought itself as historical (by opposition to what happens in the "cold" cultures described by Lévi Strauss, for example ${ }^{28}$ ). Yet this empirical historicity requires a deeper

\footnotetext{
${ }^{26}$ cf. Jacques Derrida, Le problème de la genèse dans la philosophie de Husserl, Paris, P. U. F., 1990.

${ }^{27}$ (The English version of Les Mots et les Choses must be disregarded on this point as it translates the "originaire" with the "original", which is a very unfortunate mistake).

${ }^{28}$ Cf. C. Lévi-Strauss, Race and History, Paris: Unesco, 1952.
} 
understanding of time as its own condition of intelligibility. In our current épistémè, this understanding has been (since and because of the Copernican turn) made dependent on Man as the empirico-transcendental double. Correlatively, the analytic of finitude was developed as the way in which the relation between the empirical and the transcendental could be analysed. However, this analytic turns out to be aporetic insofar as the relation between the empirical and the transcendental established by the doubles is circular: this is expressed by the theme of the "fold" (also characteristic of the originary) in which "the transcendental function comes to cover with its imperious network the grey and inert space of empiricity; conversely, empirical contents animate themselves (...) and are immediately subsumed within a discourse which furthers their transcendental presumption" (OT: 341, transl. mod.). The consequence of this is that the ground of History, i.e. the relation between Man and temporality, remains doubly obscure: we saw that it is impossible to determine precisely the way in which primordial temporality grounds empirical succession; it now appears that conversely, it is equally impossible to think the inscription of primordial temporality within the chronology of empirical time (hence the third, paradoxical meaning of the origin as originary). Because of the conjunction between this dual impossibility and the persisting demand that such connections be made, History is a highly unstable ground for contemporary thought. However, the very fact that all these impossibilities can now be diagnosed also signals for Foucault that we may be on the brink of entering a new historical a priori. As we still belong to the previous one, it is extremely difficult for us to discern its shape. Still, it is possible to say that just like the passage of the Classical Age to the age of anthropology involved the dissolution of the link between being and representation, in the same way the transition to the next épistémè will sever the grounding of History in Man. Correlatively, Foucault's diagnosis of modernity is not merely intended as a set of descriptive propositions. It is also meant to have a performative function in bringing about a new, non Man-centred épistémè, the shape of which cannot (by definition) be yet identified. Before examining briefly the consequences of this for Foucault's thought, however, I shall return to the methodological question of the nature of Foucault's activity.

We are now in a position to look more fruitfully at the question of whether Foucault is a historian or a philosopher. Insofar as he is and must remain, in Hegelian terms, the "son of his time", his work is to a large extent conditioned by History as the current historical a priori. As we have seen, this means that he is bound to see both beings and the conditions under which they are known as historical. This immediately generates a radical distance between him and the philosophers of the Classical age insofar as it leads him to think that both truth and its conditions of possibility (the "space of acceptability" his later works refer to ${ }^{29}$ ) are historical. It also makes it impossible for him to endorse the Kantian version of transcendental idealism, which is grounded in an understanding of the a priori as universal and necessary conditions. Thus Gutting is right to say that Foucault is not a philosopher "in the traditional sense": he does not believe in metaphysical essences or eternal truths, nor in the existence of a noumenal realm, nor even in the possibility of adopting a universally normative standpoint to identify atemporal conditions of possibility for knowledge. Yet this does not mean that he is a historian in the empirical sense attributed to him by Gutting. On the contrary, we have seen that the aim of chapters VII and IX was to uncover, beyond the two traditional understandings of history (historia and res gestae), a third meaning for the concept: History as our current historical a priori, the newest form of order. Crucially, neither Order nor History can be thought of as empirical: they are the conditions under which entities are constituted as orderable (in the Classical age) or historical (in the present épistémè). Thus the fact that Foucault's understanding of the transcendental is deeply qualified

\footnotetext{
${ }^{29}$ (in particular : «Critique et Aufklärung », Bulletin de la Société Française de Philosophie, n 84, p. 35-6).
} 
does not mean that he embraces positivism (which he sharply criticises precisely for having forgotten about transcendental determination ${ }^{30}$ ). Similarly, his being an empirical realist (in that he believes in the independent existence of empirical objects) does not turn him into an empiricist. As we have seen, he holds a revised version of transcendental idealism according to which these objects can only be constituted as such under conditions which themselves cannot be identified at the empirical level: History is both the "the [epistemic] space from which all beings come to knowledge" and the "fundamental mode of being of empiricities", OT: 231).

So paradoxically enough, the very fact that Foucault focused on History rules out the idea that he is a historian in the empirical sense. As suggested in the introduction, the practice of archaeology in The Order of Things is perhaps best characterised as a form of "transcendental history". This is by no means intended to suggest that Foucault succumbs to the fault Hegel was accused of (in particular by Vico), that of writing an a priori history: on the contrary, he tries to write a history of the a priori. In his attempt to historicise the transcendental, he does not introduce any extraneous metaphysical principles (such as the rationality of the real, or the idea that historical development is by nature teleological ${ }^{31}$ ). Neither does he look down on empirical history from a supposedly higher philosophical perspective, that of the "eye of the concept" 32 . By contrast, he firmly rejects this construal of history as metaphysical and grounds his approach in specific analyses of our various discursive practices. Yet his interest in empirical discourses is constantly guided by his concern to uncover their underlying conditions of possibility, in his own word to uncover "that from which knowledge [connaissance] and theories have been possible; the space of order on the background of which knowledge [savoir] was constituted" (OT: XXI-XXII, transl. mod.).

This, however, raises the difficult methodological question of the relationship between archaeology and the analytic of finitude. By contrast with the human sciences, the latter is seen as a specifically philosophical activity in that it tries to think human finitude at its most "radical" level, while the former "want to chart its empirical manifestations" (OT: 358). In Foucault's mind, this is what distinguishes both the analytic and archaeology from historicism ${ }^{33}$. Yet while archaeology shares with the analytic this critical concern for correlating empirical data with their epistemic conditions of possibility, its conclusions are very different. Contrary to the Analytic, it

\footnotetext{
${ }^{30} \mathrm{Cf}$. OT : 245 sq.

${ }^{31}$ Whether these are truly a priori is a debatable question. Thus Hegel notoriously said that while these ideas are a priori from the perspective of history, they are not so from the deeper standpoint of philosophy.

${ }^{32} \mathrm{Cf}$. Hegel: "physical perception and a finite understanding are not enough; we must see with the eye of the concept, the eye of reason, which penetrates the surface and finds its ways through the complex and confused turmoil of events" (Lectures on the Philosophy of World History: Introduction, trans. H.B. Nisbet, Cambridge UP, p. 30).

${ }^{33}$ Historicism (as a meta-reflection on historical practice) provides a critique of the human sciences by showing that the validity of their contents is constantly undermined by their inscription within the flow of history (as res gestae). It shows that "none of the contents analysed by the human sciences can remain stable in itself and escape the movement of history" (OT: 370). More precisely, historicism points out the tension between, on the one hand, the human sciences' desire for a detached and objective standpoint which would guarantee their claims a universal truth content and, on the other hand, the fact that they all belong to this very history they are trying to describe and that thus they can only have a specific, historically determined perspective. However, this critical dimension operates at a purely empirical level: it is established "solely at the level of positivities: the positive knowledge of man is limited by the historical positivity of the knowing subject, so that the moment of finitude is dissolved in the play of a relativity which we cannot escape and which itself has value as an absolute [precisely because we can't escape it]" (OT: 372, transl. mod.). By contrast, the job of the analytic of finitude as the current form of philosophy is to "reclaim what historicism has left aside: its object is to reveal, at the foundation of all positivities and prior to them, the finitude that makes them possible" (OT: 373, transl. mod.).
} 
does not identify the historical a priori with man's "mode of being" (OT: 344); nor does it hold that it is necessary to "interrogate man's being as the foundation of all positivities" (OT: 342). On the contrary, the archaeology is meant to undermine the analytic by showing that there is no necessary connection between the transcendental and Man. That we have been led to think so is the contingent result of our belonging to the current, man-based épistémè; yet part of the thrust of the Order of Things is to show that Man played no constitutive part in the prior épistémès.

Therefore archaeology has a meta-critical function towards the analytic of finitude (which itself is a critique of empiricism): it is meant to awaken us from our "anthropological sleep" (OT: 340) by showing that there is no absolute need to correlate the various historical a priori with the figure of Man. Although it shares the structure of the analytic (which could only be expected, given that to a large extent it still belongs to the same épistémè), archaeology is thus designed as a way to keep the idea of a transcendental critique alive by historicising it while invalidating its anthropocentric premises and conclusions ${ }^{34}$.

Béatrice Han-Pile University of Essex

\footnotetext{
${ }^{34}$ It is from this perspective that Foucault's writings on historiography should be understood. They are of a limited import in that they not address the specifically archaeological question of what our new épistémè will be, nor of how it will relate to History. Yet in them Foucault is clearly trying to think of alternative, non man-based ways of thinking temporality. This explains his interest for the Ecole des Annales, which started as a reaction against the previously dominant, subject-centre types of historiography (exemplified by the work of Michelet, for instance). Thus Braudel aimed at discovering, underneath the quick flow of human events traditionally charted by political history, deeper and slower forms of temporality (such as economic cycles or, at a deeper level, geological time).
} 


\section{LIST OF ABBREVIATIONS:}

OT: The Order of Things, New York: Vintage Books, 1974.

DE: Dits et Ecrits (4 volumes), Paris: Gallimard, 1994. 